\title{
A critical review of the research on Translation Psychology: Theoretical and methodological approaches
}

\author{
Lin Zhu \\ Huaqiao University, China \\ zhulin8688@163.com \\ http://orcid.org/0000-0003-3612-6177
}

\begin{abstract}
Translation Psychology, as an umbrella concept, is heterogeneous and can be investigated from different perspectives. The past few decades have witnessed the development of the cognitive-psychological approach, the social-psychological approach, the gestaltpsychological approach, and the embodied cognitive approach. These interdisciplinary approaches have spawned theoretical advances and methodological innovation, and also substantial research findings in Translation Psychology, although there are some aspects awaiting improvements. This article offers a panoramic theoretical and methodological review of these approaches: it presents their achievements, discusses the problems in their theoretical development and foresees the prospect of more integrated research on translation psychology. Multidimensional research projects on translation psychology are expected, with broader coverage of more factors influencing the translator's psychology and more holistic views of translators in their authentic, personally, socio-culturally and historically embedded environments and networks.
\end{abstract}

Keywords: translation psychology; cognitive-psychological approach; social-psychological approach; gestalt-psychological approach; embodied cognitive approach

\section{Introduction: Translation Psychology defined}

The term "psychology" may refer to the psychology of a person, that is, what makes them think or behave in the way that they do. It can also mean the scientific study of the workings of the human mind through observable behaviour (see Bolaños Medina, 2016, p. 59; VandenBos, 2015, p. 860). This is Cognitive Psychology, the scientific study of the thinking mind, and it involves the total range of psychological processes - from sensation to perception, pattern recognition, attention, consciousness, learning, memory, concept formation, thinking, 
Zhu, L. (2020). A critical review of the research on Translation Psychology: Theoretical and methodological approaches. Linguistica Antverpiensia, New Series: Themes in Translation Studies, 19, 53-79

remembering, imaging, language, intelligence, emotions and developmental process - and cuts across all the diverse fields of behaviour (Solso et al., 2005, p. 2).

Translation psychology, accordingly, may have two basic levels of meaning. On the one hand, it means the translator's psychological states in the process of translating or interpreting, as well as in the process of skill acquisition and professional development. On the other hand, it means the research area that investigates the workings of translators' minds. As a research area and a branch of Translation Studies, Translation Psychology may be defined either narrowly or broadly. In a narrow sense, it is about the psychology of the translation process and translation act itself, as defined by Holmes (1972/1988), within process-oriented Descriptive Translation Studies (DTS). It deals with the problem of what exactly takes place in the "black box" of the translators' minds as they create a new, more or less matching text in another language (Holmes, 1988, p. 72). In a broad sense, "it can be seen to comprise a great deal more than what is happening in the translating mind during the translation process" (Jääskeläinen, 2012, p. 191), because the scope of psychology is wide, ranging from cognition to affect or emotion and also personality (p.191). It investigates various aspects of the translator's psychology relevant to translation activities.

For example, it may cover the developmental psychology of the translator's skill acquisition as well as the psychological analysis of the elements and properties of the translator's mental operation. ${ }^{1}$ It may even be related to the reception psychology of the translated text. This broad sense of Translation Psychology, in general, is "a psychological angle to most translation-related phenomena, which could offer interesting avenues for fruitful, multi-disciplinary research cooperation within Translation Studies as well as with other disciplines" (Jääskeläinen, 2012, p. 192). From this broad perspective, Bolaños Medina (2016) also highlighted the multifaceted nature of Translation Psychology, which was defined as "the subdiscipline of translatology that addresses the study of translators as complex individuals functioning as a whole" (p. 59). In Bolaños Medina's (2016) view,

[t]his perspective thus embraces the underlying emotional, cognition, behavioral and social factors at play; but it also takes into account their interaction with the translators' professional environment and with other agents participating in the translation process, from both an objective standpoint and as perceived by the translators themselves (p. 59).

Therefore, Translation Psychology, as an umbrella concept, is heterogeneous and can be investigated from different perspectives. So far, the past few decades have witnessed the development of different approaches in this field, including the cognitive-psychological approach, social-psychological approach, gestalt-psychological approach, and the embodied cognitive approach (see Figure 1). 
Zhu, L. (2020). A critical review of the research on Translation Psychology: Theoretical and methodological approaches. Linguistica Antverpiensia, New Series: Themes in Translation Studies, 19, 53-79

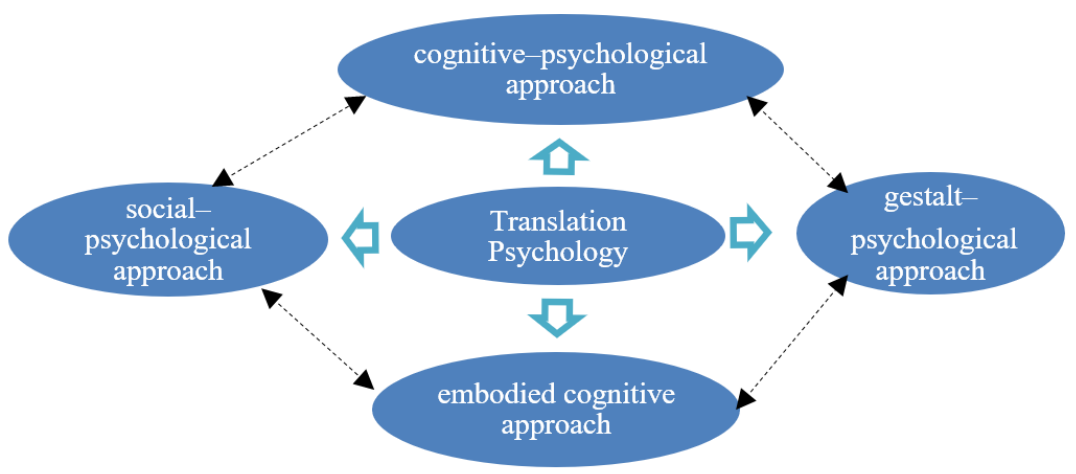

Figure 1. Different approaches to Translation Psychology

The research approaches in Figure 1 are all interdisciplinary, drawing upon research methodology and theoretical ideas from relevant disciplines or fields. The different approaches, which focus on different aspects of the translator's psychology, are interconnected and represent the complexity of Translation Psychology. In the past few decades, their development has spawned inspiring research groups, innovative research projects and methodologies and substantial research findings in Translation Studies, although there are some aspects awaiting improvements. We now consider each of these approaches more closely.

\section{Approaches and achievements}

\subsection{The cognitive-psychological approach}

In Cognitive Translation Studies, Cognitive Psychology has become one of the principal sources of theoretical inspiration. An important research area in Cognitive Psychology is language processing, including lexical access, perceptual span, word recognition, comprehension, shortterm memory and long-term memory. In this area, "cognitive psychology and psycholinguistics converged to study how people produce and comprehend language" (Jay, 2000, p. 23). The cognitive-psychological approach to Translation Studies turns to those theories and concepts about different layers and phases of language processing in cognitive psychology and psycholinguistics and investigates source text (ST) comprehension and target text (TT) reformulation in the translation process. Hatzidaki (2013) provided an overview of the multiple psycholinguistic methods and techniques to be adopted in Cognitive Translation Studies. Zasyekin's (2010) psycholinguistic text analysis using a semantic differential method helps to explain how a translator's inappropriate linguistic choices may influence the target language $(\mathrm{TL})$ readers' aesthetic reaction.

However, the "black box" of the translator cannot be directly observed and analysed. It can be investigated indirectly by collecting and analysing relevant data about the translator's 
Zhu, L. (2020). A critical review of the research on Translation Psychology: Theoretical and methodological approaches. Linguistica Antverpiensia, New Series: Themes in Translation Studies, 19, 53-79

behaviours and neural responses in the translation process and also about the linguistic features of the translated texts. Methodologically, translation process research (TPR) has drawn upon theories and methods from psycholinguistics, which have established more effective methodologies on the basis of "controlled experimental studies conducted in the laboratory, naturalistic observations in the field, case studies, cross-linguistic comparisons, and psychobiological measures" (Jay, 2004, pp. 15-16). The most commonly used empirical method for collecting data in the early period was thinking aloud (TA), an introspective way of self-reporting the ongoing mental processes of the translator (see Krings, 1987; Lörscher, 1986; Tirkkonen-Condit, 1991). Because of its much-criticized weaknesses, such as its unavoidable interference with the translator's task, its "inability to access automatic processing" (Campbell, 2000, p. 30) and the limitations of its elicited data (cf. Jakobsen, 2003, 2017), the TA method was unsatisfactory in TPR, "particularly as automatization was generally taken to be evidence of expert translation" (Jakobsen, 2017, p. 28). The more recent review on the use of verbal reports to elicit data in TPR can be found in Jääskeläinen (2017).

The development of computer technology has paved the way for new research methods in TPR. The commonly used methods include keystroke logging, eye-tracking (Alves et al., 2016; Hvelplund, 2017) and screen recording (Angelone, 2015; Ehrensberger-Dow, 2014), which were employed to collect observable data of "what the translator actually did during the translation process as opposed to what they think they did" (O'Brien, 2011, p. 3). Besides these methods, brain-imaging techniques and neurophysiological measures, such as fMRI scans (Hervais-Adelman et al., 2015), EPR (Proverbio et al., 2004), PET scans (Rinne et al., 2000) and EEG (Elmer et al., 2010), have been used to detect the active parts of the brain with certain cognitive processing or in response to certain stimuli by measuring relative neurophysiological indexes.

Research projects using those techniques need to be well designed: the questions asked and the steps of measurement should be combined with expertise in relevant areas and careful consideration of the advantages and disadvantages of laboratory studies. Hatzidaki's (2019) discussion of methodological issues in experimental research in Translation Studies is helpful in improving this line of research. Investigating aspects of cognitive psychology involves sets of hypotheses and requires systematic research designs. As Jay (2004, p. 16) observed, "Research is generally not a 'one-shot deal' but a programmatic one, asking a series of questions that converge on an answer to a particular problem." In this light, any experimental method mentioned above can hardly test a set of hypotheses when used on its own. Different methods and techniques, therefore, should be mutually complemented in data collection and analysis in order to shed light on the nature of the translation process.

In summary, data-collection methodologies in Translation Studies could be process-, product-, participant- and context-oriented, as indicated in Figure 2. This figure offers a systematic view of the approaches to probing the mental process of translating on the basis of a summary of the major research methodologies engaged in to date in Translation Studies (cf. Saldanha \& 
Zhu, L. (2020). A critical review of the research on Translation Psychology: Theoretical and methodological approaches. Linguistica Antverpiensia, New Series: Themes in Translation Studies, 19, 53-79

O'Brien, 2014). It may, of course, not cover all the possible approaches, but it does indicate substantial methodological progress in this field in the past few decades.

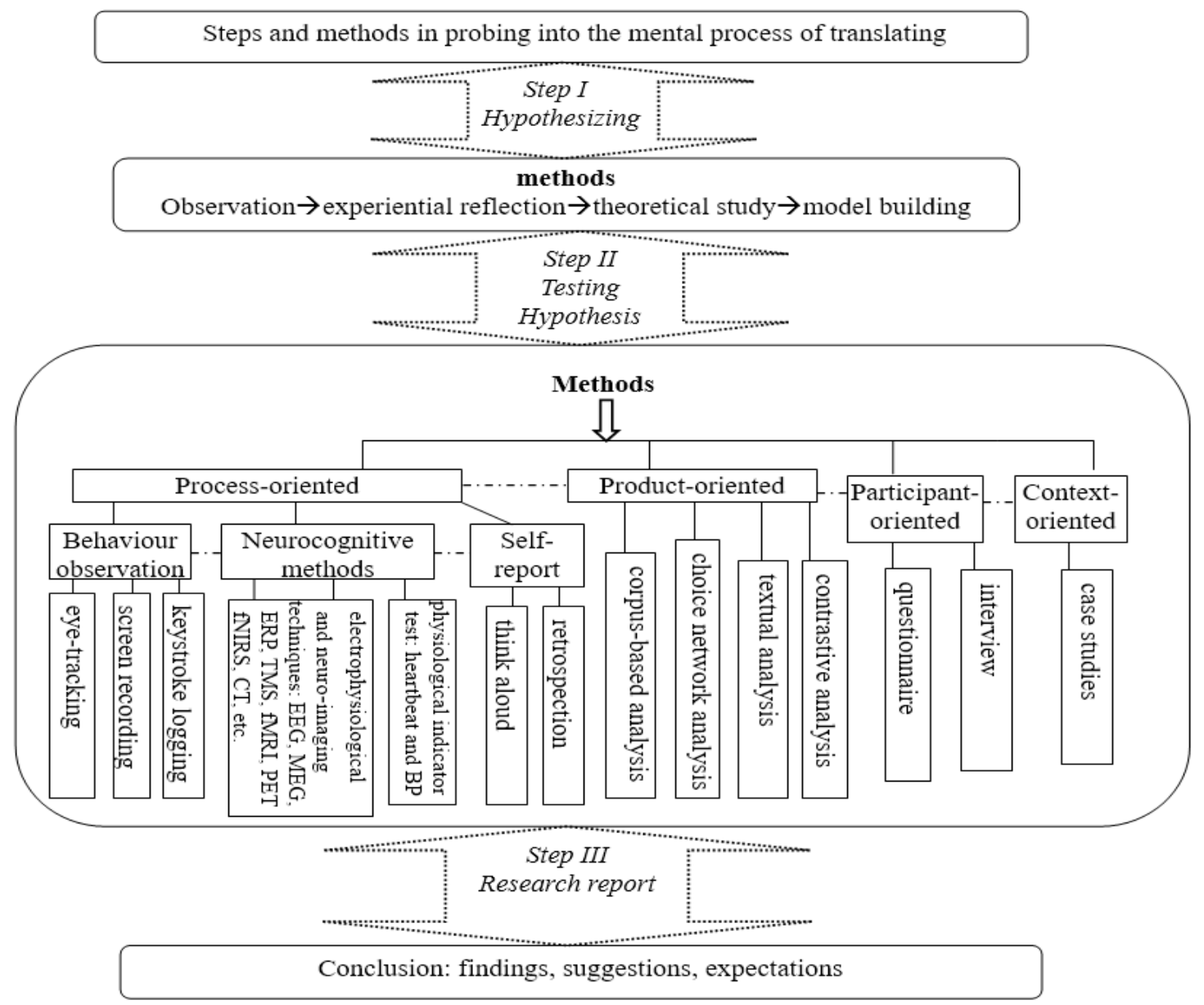

Figure 2. The steps and methods for probing into the mental process of translating

Scholars in Cognitive Translation Studies have formed some research groups and become increasingly connected with each other by joint research projects, seminars and publications. The TREC (Translation, Research, Empiricism and Cognition) network has been set up as a bridge that currently links 65 researchers from 35 universities in 18 different countries distributed throughout Europe, Asia, Australia and the Americas. They are united by their joint interests in empirical and experimental research on the translation process, especially with respect to cognition. The network includes such well-known groups or centres as CRITT, LETRA, PACTE and PETRA and CSTIC. ${ }^{2}$ Their research issues involve translation competence and expertise, cognitive cost and rhythm of the translation process, translation community, professional translation tools and environments, etc. ${ }^{3}$

The pioneering studies on the cognitive-psychological approach, represented by Krings (1987) and collected papers in Danks et al. (1997), O'Brien (2011), Shreve and Angelone (2010), etc., present the first steps in "formalizing the cooperation between cognitive psychology, 
Zhu, L. (2020). A critical review of the research on Translation Psychology: Theoretical and methodological approaches. Linguistica Antverpiensia, New Series: Themes in Translation Studies, 19, 53-79

neurology, bilingualism studies, and the applied fields of translation and interpreting" (Shreve \& Koby, 1997, p. xviii), and the

continuing methodological innovation, an increasing attention to research standards and research design, and an increasing commitment to the integration of research results with the findings and research apparatus of the disciplines of cognitive science (Shreve \& Angelone, 2010, p. 6).

Further development of the cognitive exploration of translation and interpreting has also been witnessed in more recent publications by Carl et al. (2016), Ferreira and Schwieter (2015), García (2019), Göpferich et al. (2011), Mees et al. (2009), Rojo and Ibarretxe-Antuñano (2013) and Schwieter and Ferreira (2017), among others. Focusing on theoretical advances and methodological innovation, they have presented the increasing diversity and ever-deepening exploration of various cognitive aspects of translation and interpreting: cognitivepsychological, psycholinguistic, neurocognitive and cognitive-linguistic explorations. These studies, including their findings, data-collection methods, tools and techniques, have shed new light on further research on translation psychology.

Regarding cognitive-psychological models of translating and interpreting, the main theoretical framework in the early period was the psychological version of the informationprocessing model from machine translation. Bell's (1991) model is representative, based as it is on information-processing theories of cognitive psychology and extensive knowledge of linguistics (including text linguistics, systemic-functional linguistics, semantics and pragmatics). The whole process of translating, as Bell (1991, p. 60) argued, can be modelled as a cascaded and interactive process that consists of three major processing stages: syntactic, semantic and pragmatic. For the first time, Bell's model offered an integrated cognitive model of the translation process.

In addition, Kiraly (1997) presented a psycholinguistic model of the translation process which covered not only the controlled process of mental space but paid special attention to the uncontrolled intuitive workspace in the translator's brain. This is a noticeable aspect, one distinct from some studies in TPR that focused only on the rational, conscious level of workspace in laboratory conditions and ignored the intuitive level of the translation process. In fact, the psychology of the translation process involves both the conscious and the unconscious (intuitive) aspects of processing (Gabryś-Barker, 2009, pp. 26-33) and intuition has always been an indispensable element of it, as has been argued by many scholars (see Hubscher-Davidson, 2013; Kiraly, 1995; Komissarov, 1995; Robinson, 1991, 1997; Wilss, 1996 ).

Other well-known psychological models of translating or interpreting were proposed in Gerver (1976), Moser-Mercer (1978, 1997), Setton (1999), which, similar to the models in Bell (1991) and Kiraly (1997), were invariably developed out of the monolingual language comprehension and production theory in cognitive psychology. They focus on the explanation of the serial procedure of information processing from source-language $(\mathrm{SL})$ comprehension to meaning 
Zhu, L. (2020). A critical review of the research on Translation Psychology: Theoretical and methodological approaches. Linguistica Antverpiensia, New Series: Themes in Translation Studies, 19, 53-79

transfer and then to reformulation in the target language (TL) at various linguistic levels (phonological, lexical, syntactic and semantic). However, they neglected the bilingual parallel procedure of information processing in the translating and interpreting process (see Section 3 for a detailed discussion of the problem). ${ }^{4}$

In China, the past decades have also witnessed the publication of monographs and papers on the cognitive psychology of translation between English and Chinese. The earlier studies are mainly theoretical contributions from the perspective of cognitive psychology and psycholinguistics, such as those of Li and Liu (2008), S. Liu (2007), H. Liu (2009) and Yan (2008), which explored how to apply the theories of cognitive psychology and psycholinguistics to Translation Studies. More specifically, Yan (2008), similar to Bell (1991), drawing from information-processing theories and memory theories, and discourse analysis theories, analogically formulated the cognitive model of translation, describing the cognitive process of different layers of comprehension and the production process of translating. Yan's (2008, p. 61) model, in its nature, is very similar to Bell's, although it adopts different terms to describe the two stages of comprehension and production. The major difference between them is that Yan added pre-translation and post-translation stages to the psychological model and highlighted the impact of the translation intention on the translation process and the choice of the ST.

Another difference is that Yan (2008) briefly mentioned translation thinking by drawing on the theory about thinking patterns from psychology and the relevance theory from cognitive pragmatics. In brief, Yan (2008) offers basic knowledge of cognitive psychology in comprehension and production and puts forward the psychological analysis of different stages of translation respectively, including lexical, sentence and textual comprehension, and lexical choice and the translation of meaning, intention, situation and pragmatic intention (see Yan, 2008, p. 61). It could be regarded as an introductory text for those readers who also need to know more about cognitive psychology and translation.

In contrast to Bell (1991) and Yan (2008), who separately described the processing mechanism of comprehension (analysis) and production (synthesis) in the translation process, S. Liu (2007) decomposed the psychology of translation into different cognitive elements in his explanation by drawing on relevant theories of cognitive psychology. S. Liu introduced each element of human cognition respectively and discussed their individual influence on the corresponding elements of translation psychology without integrating them into a more comprehensive explanatory framework of the translation process from a holistic perspective. This way of segmenting the translator's psychology cannot provide a global view of the translation process, which, because of the complexity and connectionism of human cognitive psychology, is not a simple combination of those segments (see Jay, 2000, 2004). Besides, Bell (1991) and Yan (2008) focused mainly on translating, whereas S. Liu also touched upon the psychology of interpreting.

The empirical research on the translation process between English and Chinese has been developed recently in China. It has been presented mainly in a few doctoral theses, such as those by J. Feng (2018), and papers (e.g., those by Dong \& Lin, 2013; Kang, 2018; Lin \& Dong, 
Zhu, L. (2020). A critical review of the research on Translation Psychology: Theoretical and methodological approaches. Linguistica Antverpiensia, New Series: Themes in Translation Studies, 19, 53-79

2011; Lin et al., 2015; Lu \& Sun, 2018; Zhao, 2013). The empirical studies come mainly from two circles: one is the circle of Translation Studies scholars who are interested in TPR, and the other is the circle of Psycholinguistics scholars, who have focused on psycholinguistic issues in interpreting. In the former circle, for example, J. Feng (2018) investigated the difference in attention allocation in the directionality of translating between English and Chinese, using eye-tracking and keylogging methods, and confirmed the hypothesis that the cognitive load during $\mathrm{L} 2$ translation is higher than that during L1 translation. The eye-tracking study by Lu and Sun (2018) found, in addition, that the cognitive efforts of translators in post-editing tasks were more heavily influenced by the text type than by their language proficiency. In the latter circle, for example, Zhao (2013) provided some support for the horizontal processing theory and concluded that task schemas play a very important role in interpreting. In addition, Lin et al. (2015) observed the hierarchical relationship in resource allocation between ST comprehension and TL reformulation in interpreting. Based on the distinct advantages of the two circles, the joint research between them may produce more fruitful research findings.

A distinct sphere of research referred to as "translation thinking" exists in China; it can be classified under Translation Psychology because thinking constitutes the most complex component of cognitive psychology. But this field of research was hardly found in Western publications, perhaps due to the greater difference in the mode of thinking between Western language speakers and Chinese speakers than that between Western language speakers, as argued by Huang (2012). Translation thinking is concerned with the specific cognitive processes of bilingual and bicultural understanding and transfer in the translation process.

Traditional research on translation thinking is mainly experiential and theoretical, and it focuses on three aspects:

- the blueprint for establishing the discipline of translation thinking (Gong, 2004; Zhang, 2001);

- the cultural and thinking differences between Chinese and Western languages and their influence on translation (B. Wang, 1992; Y. Wang, 2001); and

- various types of thinking from the perspective of the translation process, such as monitoring, metaphorical, abstract, image, intuitive and logical thinking (e.g., B. Feng, 1994; H. Wang, 2002).

The research on translation thinking highlights the particular nature of translation between English and Chinese. With the development of modern technological tools for Cognitive Translation Studies, it is believed that the incorporation of empirical methods will stimulate this line of research.

In summary, the cognitive-psychological approach explores the mental operations of translating in such aspects as consciousness and cognitive effort, working memory and longterm memory, automaticity, novice and experts, bilinguals and translators, variability in translation, cognition and the evolution of translation competence, a professional translator's 
Zhu, L. (2020). A critical review of the research on Translation Psychology: Theoretical and methodological approaches. Linguistica Antverpiensia, New Series: Themes in Translation Studies, 19, 53-79

self-concept, reading and translation, and the psychology of interpreting. It has laid a solid ground for comprehensive research into translation psychology, although it simultaneously exposes certain deficiencies in the theoretical and methodological aspects of this research, deficiencies that are aired in Section 3 below.

\subsection{The social-psychological approach}

The social-psychological approach to Translation Studies investigates the psychological features and processes of the translator not only as a bilingual agent but as a social member of the translation marketplace situated in certain sociocultural contexts (see Risku, 2014 Robinson, 2001). This approach has been regarded more as a theoretical perspective on translation and translators. In it, the translator is seen as an emotional, active and creative mediator between two languages and cultures in general and also between two texts (ST and TT) in particular.

The translator's decision-making is inevitably influenced by multiple factors in society as a conglomerate of various socio-cultural systems, such as patronage, ideology and poetics (see Lefevere, 1992). Scholars in this theoretical perspective are interested in investigating the heterogeneous inner state of the practising translator in dealing with diverse texts under the influence of various social factors. This exploration can draw theoretical ideas from multiple disciplines, such as sociology, social psychology, communication theory, philosophy, linguistic sub-disciplines and cultural studies.

The "cultural turn" of the 1980s has broadened the horizon of Translation Studies by situating translation in a broader sociocultural and historical context. The translator's social psychology in the broader context has received more attention and has been touched upon by a few scholars. Chesterman's (2009) proposal of "Translator Studies" places the translator in focus and brings together translation process research and translation sociological research, among other points of focus, which partly overlaps with the scope of the social-psychological approach (also see Jääskeläinen, 2012, p. 196).

Robinson (1991) put forward "the translator's turn" in the climate of the "cultural turn" of translation Studies, which highlighted translator-oriented research. His translator-centred theories (as in Robinson, 1991, 1996, 1997, 2001, 2003), from a social-constructivist perspective, "present a deep concern for the translator's social status, working environments, translation process, social-psychological characters, etc." (Zhu, 2012a, p. 27). These theories invariably challenge the traditional assumption of the dualistic, rationalist, instrumentalist and perfectionist conceptions of the translator's absolute submission to the ST author, and reformulate the translator's social cognitive characteristics and process (see further in Zhu 2012a). For instance, Robinson's (1991) somatics of translation explains "the translator's social-psychological process - a process that integrates the translator's personal and unique (idiosomatic) experience with the translator's response to the community's (ideosomatic) programming" (Zhu, 2012a, p. 142). 
Zhu, L. (2020). A critical review of the research on Translation Psychology: Theoretical and methodological approaches. Linguistica Antverpiensia, New Series: Themes in Translation Studies, 19, 53-79

In addition, Robinson's (2001) theory of post-rationalist translator subjectivities argues against the rationalist view of translator subjectivity that presupposes the translator's psychology of pure reason, and brings to the fore the translator's heterogeneous inner state, both rational (consciously analytical) and intuitive (unconsciously analytical), in the multiply-voiced translation marketplace where "translations are produced less and less by individual translators, more and more by disaggregated agencies consisting of project managers, editorial assistance, freelance translators and research assistance" (Robinson, 2001, p. 193). Moreover, Robinson (2003, p. 93), with his figure of "the wheel of experience", illustrates the psychological process of the translator's socialized transformative process of professional development.

In summary, the above theories of Robinson present his social-psychological approach to translation, which focuses on the heterogeneity of the translator's psychological structure and the socialized process of the translator's psychological development and decision-making in translating. They demonstrate the tension between personal creativity and social (interpersonal) regulation in the translator's psychology (see Robinson, 1991, 2001, 2003).

Simeoni (1998) applied Bourdieu's sociological notion of habitus to his research on the translator's social psychology of shaping the habitus. Simeoni (1998) pointed out that the important point here is not to reduce the translator's habitus to a collection of purely intellectual skills or a mindset. It is an embodied, somatic disposition comprising affective and cognitive dimensions (cf. Hermans, 1999, p. 135). This develops habitus into a productive concept for investigating the translator's psychology in shaping various translation experiences.

In addition, Risku (2002, 2010, 2014) and Risku and Windhager (2013) focus on how to use the concepts of embodied, extended and situated cognition as methodologies for developing research on the "socio-cognitive aspects of [the] translation process" (see Risku, 2014; Zhu, 2018, p. 136). The research on the cognitive ergonomics of translation (as Ehrensberger-Dow \& Massey, 2014) also contributes to knowledge about the distributed cognition features of the translator's psychology. Generally speaking, these studies, with their attention to the "historical and environmental embeddedness of cognition in translation" (Risku, 2014, p. 336), also belong to the social-psychological approach discussed in this section.

In China, the social-psychological approach has been less developed than Sociological Translation Studies has. Very few studies in this area have been found so far. One such study is that of Zhu (2017), who drew upon Bandura's (1986) social cognitive theory of triadic reciprocal determinism to put forward a social-cognitive way of thinking about translation norms. This theory is centred on the translator's social-cognitive psychology (see Figure 3 below). 
Zhu, L. (2020). A critical review of the research on Translation Psychology: Theoretical and methodological approaches. Linguistica Antverpiensia, New Series: Themes in Translation Studies, 19, 53-79

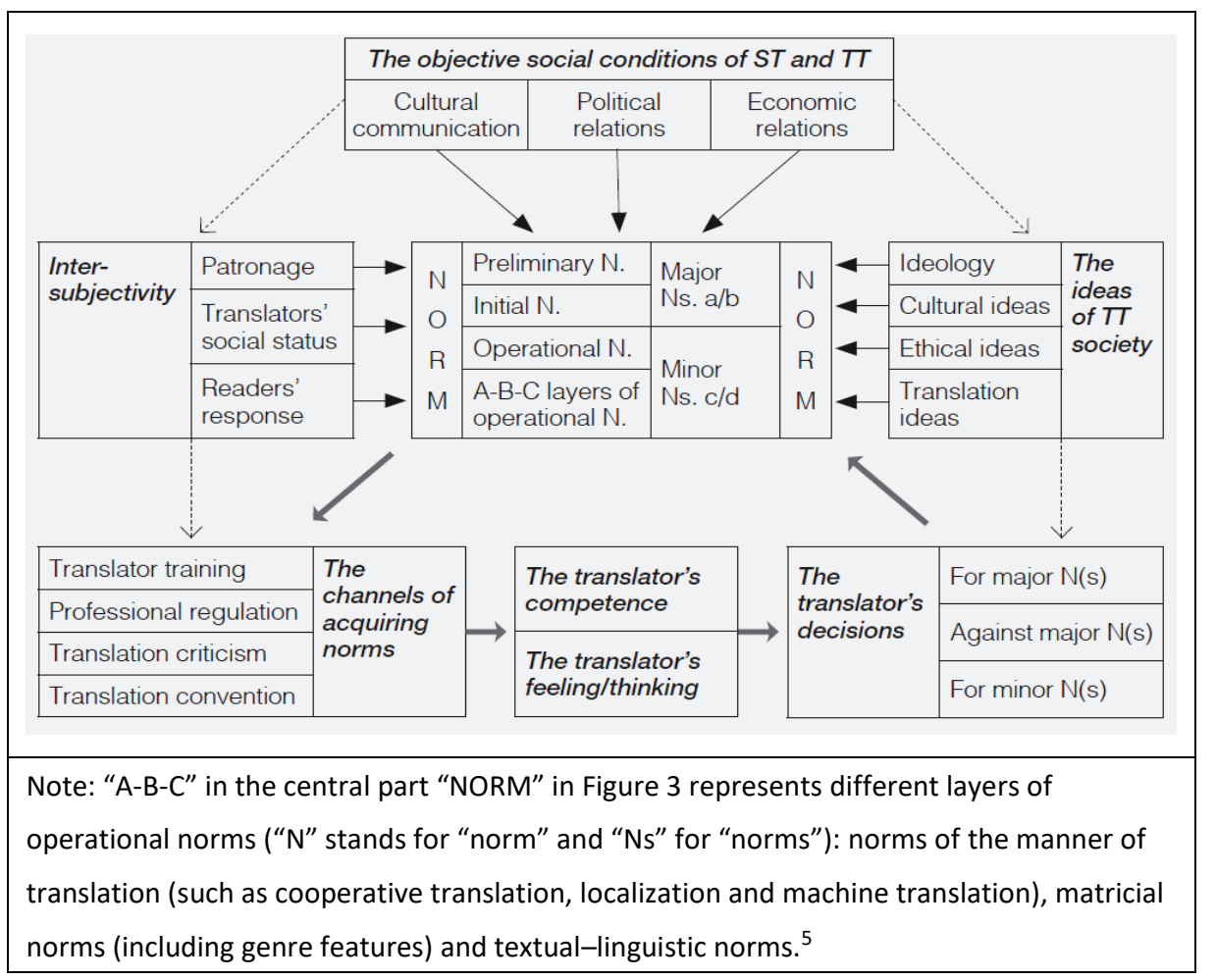

Figure 3. An integrated description of translation in its sociocultural context (see Zhu, 2012b, p. 75)

In Figure 3, the sociocultural, textual (linguistic), psychological and ideological factors involved in the translation process are all incorporated into this model. All the parts extending arrows towards the central part NORM present the influencing factors of translation norms. The looping connection by arrows connecting the three parts below (i.e., the channels of acquiring norms, the translator's competence and their feeling/thinking, and the translator's decisions) to the central part NORM constitutes the dynamic process of norm-regulating translation. The dotted lines connecting any two parts in the figure signify the relationship of influence between them. The part facing the arrow is influenced by its opposite (see Zhu, 2012b, p. 73).

In addition, from the embodied cognition perspective, Zhong and Zhu (2015) explained in detailed the embodied, integrated and systematic features of the translator's social-cognitive psychology. Here they focused on the architecture of the translator's social-psychological process and the mechanism of the translator's embodied bilingual processing. In fact, Sociological Translation Studies, with its broad horizon of translation in society, can provide theoretical inspiration for research on the social psychology of the translator. With increasing recognition of the inseparability of translation from its given sociocultural and interpersonal contexts, the translator's social psychology will necessarily receive more and more attention and through this the social-psychological approach will stimulate more integrated research on translation psychology. 
Zhu, L. (2020). A critical review of the research on Translation Psychology: Theoretical and methodological approaches. Linguistica Antverpiensia, New Series: Themes in Translation Studies, 19, 53-79

\subsection{The gestalt-psychological approach}

Gestalt psychology, as a theory of mind and brain, maintains that the brain is holistic, parallel and analogue, with self-organizing tendencies, and because of this we perceive things in their entirety before perceiving their individual parts. The holistic principle of human perception underlies the holistic approach to comprehension. To put it simply, our mind tends to establish connections between various stimuli even though they seem not so coherent in a given context of comprehension. This principle has been applied to and reformulated in other disciplines such as Linguistics (as in discourse comprehension, linguistic and prototype gestalt), Literary Studies (as in reception aesthetics) and Translation Studies (in textual comprehension and reconstruction).

The gestalt-psychological approach to discourse comprehension and literary reception has shed light on Translation Studies in the sense of considering the translator's comprehension of the ST and reconstruction of the TT. In her monograph, Aesthetic Progression in Literary Translation: Image-G Actualization, Jiang (2002) proposed the gestalt quality of images in literary works and argued that

the gestalt image in literary work of art is found to possess two features: it establishes a pattern within a textual organization, focusing on the meaning of a textual organization as a whole; it creates gestalt qualities such as atmosphere, tone (p. 72).

Jiang (2002) developed the concept of image-gestalt (Image-G) in literary reception and proposed an image-gestalt translation model in literary translation on the basis of her position that "when the original text is actualized in the translated text in a gestalt image, higher aesthetic equivalence will be acquired" (p. 40).

More specifically, Jiang explained the gestalt perception of linguistic structures and literary images and also their actualization in the translation process. In addition, she explained the psychological faculties that contribute to the active operation in the image- $G$ actualization, which include the imaginative faculty and the reflective or accommodative operation. The psychological mechanism of image-G perception and actualization in literary translation contributes to further research on the complex psychology of the literary translation process.

In contrast to Jiang's gestalt-psychological approach to the literary translation process, SnellHornby (1995), in a broader view, argued for an integrated approach to Translation Studies, one based on a dynamic and gestalt-like system of the relationship between basic text types - as prototypes - and the crucial aspects of translation. As Snell-Hornby (1995) stated, "it is the holistic principle of the gestalt that will be essential in our integrated approach to translation" (p. 28). Inspired by gestalt psychology, Snell-Hornby's integrated approach, in fact, was aimed at epistemological improvement in Translation Studies and for the purpose of shaping "our conception of translation studies as an integrated and independent discipline that covers all kinds of translation, from literary to technical" (Snell-Hornby, 1995, pp. 34-35). The two major 
Zhu, L. (2020). A critical review of the research on Translation Psychology: Theoretical and methodological approaches. Linguistica Antverpiensia, New Series: Themes in Translation Studies, 19, 53-79

epistemological aspects improved should be the replacement of the rigid objectivist concept of text typology with prototypology. Prototypology is based on the blurred edges and overlappings of category members (a gradual transition of text types) and the substitution of a top-down approach (integrated) to Translation Studies for the traditional bottom-up approach because "an analysis of the parts cannot provide an understanding of the whole" (Snell-Hornby, 1995, p. 35).

In summary, from different angles, Jiang (2002) and Snell-Hornby (1995) applied the gestalt principle of human perception to different levels of Translation Studies, one to the translation psychology of literary translation and the other to the epistemology of Translation Studies.

\subsection{The embodied cognitive approach}

The embodied cognitive approach to Translation Studies draws epistemological and methodological inspiration from the embodied cognition paradigm underlying the second generation of cognitive science (Lakoff \& Johnson, 1999). For embodied cognitive scientists, experiences of the body are represented as ideas in the mind, and the body provides valuable resources for offloading cognition in such a way that the mind is distributed across the brainbody-world interactions (Lakoff \& Johnson, 1999, p. 12). Therefore, cognition is not simply embodied but also (environmentally and experientially) situated, (socially and culturally) extended and embedded, and (body-world-mind-interactively) distributed (see Clancey, 1997; Clark, 1997, 1999; Dawson, 2014).

The idea of embodied cognition has shed light on language performance, including translation/interpreting (as a complex and embodied cognitive task), and has revealed the embodied nature of language and translation. It has therefore provided conceptual and theoretical underpinnings for research on the cognitive aspects of translation (O'Brien, 2013). The concepts of embodied, extended and situated cognition as methodologies have been adopted to help develop research on the socio-cognitive translation process (see Risku, 2002, 2010, 2014; Risku \& Windhager, 2013). The scholars who work within the embodied cognitive translation paradigm maintain that the translation process should be examined in terms of translation networks, actors and environments. They argue for "a comprehensive picture of the dynamics and the embodied, extended and situated cognitions involved in translation processes" (Risku, 2014, p. 333).

In addition, Muñoz Martín (2010a, 2010b, 2013, 2014, 2016) argued for Cognitive Translatology as a sub-discipline of Cognitive Translation Studies characterized by its two commitments (namely, empirical and cognitive) and by the use of the common grounds of the second-generation cognitive paradigms referred to above as a referential framework. As an applied scientific discipline, Cognitive Translatology seeks to improve translation quality, processes and training. Expertise therefore lies at the core of its endeavours (Muñoz Martín, 2014 , p. 3). From this embodied perspective, Muñoz Martín (p. 3) and his colleagues in the PETRA research group (now at the MC2 Lab of the University of Bologna, Italy) have conducted 
Zhu, L. (2020). A critical review of the research on Translation Psychology: Theoretical and methodological approaches. Linguistica Antverpiensia, New Series: Themes in Translation Studies, 19, 53-79

research on the embodied cognitive psychology of the professional translation process and also on professional translation abilities and translator training. Based on their research, they put forward the characteristics of the embodied cognitive psychology of professional translator training and training methods (Olvera Lobo et al., 2007, 2009).

Christensen (2011) - applying the embodied view of cognition, especially the distributed view of cognition in this paradigm - argued that the translator's mental process in translation memory (TM)-assisted translation is a distributed cognitive phenomenon across individuals and across internal and external representations, which are termed artefacts, and therefore also argued for the necessity of investigating the impact of TM tools on mental cognitive processes. Moreover, she also suggested that studies which combine the investigation of what happens in the individual translator's mind (internal processes) with what happens in the translator's environment (external processes) are needed in order for us to learn more about situated and distributed translation and the increasingly relevant role played by tools and teams (Christensen, 2011, p. 155).

In China, the embodied cognitive approach in the research on language and cognition is mainly represented by Cognitive Linguistics. Cognitive-linguistic theories and concepts are employed to explain the cognitive psychology of the translating process (e.g., Rojo \& Ibarretxe-Antuñano, 2013). This is also a mainstream of Cognitive Translation Studies in China, as presented by the recent publications Cognitive Translatology (Wen \& Xiao, 2019) and Prolegomena to Cognitive Translatology: Cognitive Paths and Constraints of Creative Translation (Tan, 2012). ${ }^{6}$ Other representative researchers in this area include Ding (2011), H. Liu (2009), Ma (2016), Xiao (2017) and Yan (2016). Theirs are all cognitive-linguistic studies of the translating process, drawing upon such theories as cognitive grammar, frame semantics, conceptual integration, image schema, categorization and mental space blending.

Based on the corpus of translation between English and Chinese, these studies provide new propositions on the psychology of the translation process. For example, Yan (2016) argued that translation is a cognitive process of recategorization. H. Liu (2009) explained the cognitive-linguistic operations in Chinese-English (C-E) translation, such as cross-lingual metonymic substitution, event-reconceptualization and re-lexicalization of motion-event in CE translation. Xiao (2017) elaborated on the frame operations in poetry translation. Tan (2012) explained the translator's psychology of creativity from the perspective of cognitive linguistics. These studies have also provided some inspiration for further research on translation psychology, particularly on the psychological process relevant to the translator's decisionmaking.

In summary, the four approaches to the research on Translation Psychology, drawing different theoretical inspiration from relevant psychological studies, have demonstrated their respective advantages in exploring the different layers or aspects of the heterogonous nature of translation psychology. Preliminary as they are, these approaches are in the process of improvement, needing to incorporate more aspects involved in the psychology of the 
Zhu, L. (2020). A critical review of the research on Translation Psychology: Theoretical and methodological approaches. Linguistica Antverpiensia, New Series: Themes in Translation Studies, 19, 53-79

translation process at both the social-psychological level and the cognitive-psychological level (see Section 3.2 for detailed suggestions).

\section{Problems and prospects}

\subsection{Problems}

Investigation of the psychological translation process, as mentioned, has notched up certain achievements in probing into the process of the translator's mind from the perspectives of cognitive psychology, social psychology and gestalt psychology. Those approaches to the investigation, however, also present certain problems in both the methodology and the epistemology of the research. The cognitive-psychological approach was based mainly on the rationalist, disembodied perspective on cognition, which is rooted in the longstanding Western philosophy of mind-body dualism (see Muñoz Martín, 2016).

Bell's (1991) model, S. Liu's (2007) formulation and Yan's (2008) model, from a disembodied perspective, all put emphasis on the translator's information processing in the stages of ST decoding and $T T$ recoding respectively, without considering the manner in which the variety of the translator's social psychology (shaped by their embodied experience) may influence those stages of processing. This rationalist epistemology of the cognitive-psychological approach, which regards the mind as a disembodied/depersonalized computer, originates in the same rationalist philosophy that underlies the traditional (disembodied) cognitive psychology from which the cognitive-psychological approach draws theory.

Another noticeable problem with the cognitive-psychological approach lies in its theoretical bases being invariably related to monolingual processing without reference to the relevant studies of bilingual psychology. In fact, there are both similarities and differences between the psychology of non-translator bilinguals and translation psychology as a special case of bilingual processing. Therefore, it is difficult to conduct effective research on translation psychology until we have a good mastery of the progress made in the research on bilingual (cognitive) psychology, which developed much earlier and more productively. As Shreve (2012) pointed out, "Any comprehensive model of translation competence must necessarily accommodate empirical findings about the nature of the bilingual brain" (p. 2).

Indeed, research on bilingualism has provided us with fundamental knowledge about bilingual brain and memory, lexical access, lexical selection and bilingual control. The relevant findings in the above cognitive aspects underlie any research because translation psychology, first of all, is about bilingual processing. Halverson (2010, p. 353) also argued that a cognitive theory of translation must integrate a cognitive theory of bilingualism and pointed out that the task of combining a general theory of language and a specific theory of bilingualism requires finding theories that are compatible in their most fundamental assumption. This is why bilingualism 
Zhu, L. (2020). A critical review of the research on Translation Psychology: Theoretical and methodological approaches. Linguistica Antverpiensia, New Series: Themes in Translation Studies, 19, 53-79

research becomes one of the theoretical underpinnings of the research on Translation Psychology.

In addition, a more noticeable weakness of the cognitive-psychological approach is its lack of detailed and convincing illustration of the way in which the ST decoding stages are cognitively connected to the TT recoding stages in those cognitive models, although some of them generally indicate certain connections between the two stages. These include semantic, pragmatic and syntactic connections, as presented in Bell's and Yan's models (see other models in Hansen (2008) and Wilss (1996)). The comprehension stage and the translation (reproduction) stage in this approach are treated principally as only two consecutive steps without any consideration of their concurrent processes.

As a matter of fact, the translator's processing in the two stages is both serial and parallel, which gives rise to a complicated psychological process comprising multiple levels of connections between ST decoding and TT recoding, as argued by Translation Studies scholars (Carl \& Dragsted, 2012; Danks \& Griffin, 1997; Kussmaul, 1997) and cognitive psychologists (De Groot, 1997; Dong \& Lin, 2013; Gerver, 1976). The former group of scholars maintained the inseparability of comprehension and production in the whole translating/interpreting process; the latter group corroborated the parallel processing of the TL during SL comprehension by multiple approaches of experimental studies.

Moreover, the two stages, mutually influenced and interconnected in the translation process, are much more complex than monolingual comprehension and production. As Shreve and Lacruz (2017) argued: "An important future thread of research in cognitive translation studies will be to explain how the fundamental models of bilingualism can be fruitfully used to understand translation" (p. 138).

The complexity of the bilingual processing in the two stages should be a focus of a cognitive investigation into the translating process. The studies in the cognitive-psychological approach mentioned above, mainly dealing with comprehension and expression separately, were unable to achieve that goal, though.

In contrast to the cognitive-psychological approach that pays more attention to the translator's rational information processing and disregards the translator's embodied experience shaped in a given social context, the social-psychological approach emphasises the socially shaping process of translation psychology and highlights the translator not only as a creative, personalized individual but as a socialized one with certain social and professional norms internalized in their psychology. But the social-psychological approach, owing to its broader socio-cultural concern, easily neglects to pay attention to psycholinguistic considerations. Therefore, the cognitive-psychological and the social-psychological approaches, as two different layers of research, rarely have intersections. However, the two layers should be complementary to each other and the relevant factors influencing translation on the two layers should be integrated into a holistic view of the translator's cognitive 
Zhu, L. (2020). A critical review of the research on Translation Psychology: Theoretical and methodological approaches. Linguistica Antverpiensia, New Series: Themes in Translation Studies, 19, 53-79

psychology. Chesterman (2009) argued for more comprehensive Translation Studies, which places the translator in focus and brings together translation process research and sociological research on translation (see Jääskeläinen, 2012, p. 196).

The point here is to seek an effective means of integration in further research, which should be translator-oriented and integrate the linguistic, literary, textual, sociocultural and even political and economic factors into a comprehensive framework for explaining the psychology of translation. This integrated approach to research was outlined in the expanded "Translator Studies" by Bolaños Medina (2016, p.69), whose starting point is Chesterman's (2009) conception of "Translator Studies". This expanded outline includes more psychological perspectives (as cultural psychology, social psychology, organizational psychology, differential and personality psychology and educational psychology), which, classified into three categories of instrumental focus, individual's functioning focus and applied focus, are neither systematic nor logically clear in the classification of the research field. Systematically, research perspectives, research areas, research methods (including instruments) and applied research should be different categories in a hierarchical research proposal of Translation Psychology.

According to the holistic way of thinking, the gestalt-psychological approach should be most inspiring in the epistemology of Translation Studies. The holistic principle of human perception has inspired us to adopt not only the holistic approach to translation psychology (of gestalt feature) but also the integrated approach to Translation Studies as both an independent discipline and an interdiscipline. As Snell-Hornby (1995) pointed out:

Translation draws on many disciplines, but is not equal to the sum total of their overlapping areas and is not dependent on any one of them. As a discipline in its own right, translation studies needs to develop its own methods based not on outside models and conventions from other disciplines, but on the complexities of translation. (p. 35)

Indeed, an integrated approach to translation problems not only conforms to the holistic principle of human perception but is based on the complexity of translation psychology. The integrated approach, however, does not mean a once-and-for-all solution to the problems of translation. It not only means methodological cooperation between neighbouring disciplines and research fields but also requires the epistemological inclusion of a broader spectrum of elements involved in the whole translation process and in the web of various relationships concerning translation and translators (as individuals and/or groups). This integrated approach concerns epistemological and methodological innovation, which is crucial to the development of Translation Studies towards a well-developed science. As Wilss (1982) pointed out, "what distinguishes the modern science of translation from previous consideration of translation theory is its interest in knowledge of methodology and its keener awareness of the problems involved" (p. 53). The abovementioned problems with the different approaches can inform us of the direction of methodological improvement. 
Zhu, L. (2020). A critical review of the research on Translation Psychology: Theoretical and methodological approaches. Linguistica Antverpiensia, New Series: Themes in Translation Studies, 19, 53-79

\subsection{Prospects}

In research on translation psychology, it is suggested that scholars from the integrated perspective take the following three aspects into consideration in their further research:

- The complexity of translation psychology as an integrated and dynamic system of cognition comprising multilevel processing and concerning multilayer contexts (textual, social, cultural and communicative).

- Integrated research on translation psychology should incorporate multiple perspectives (as the cognitive-psychological, the social-psychological, the gestaltpsychological, the embodied cognitive perspectives, etc.) into systematic thinking about the enquiry into translation psychology.

- The research on translation psychology should be translator-centered, highlighting the translator's embodied cognition shaped by their embodied experience as a complex combination of various personal, social (interpersonal) and professional experience.

In fact, the above three aspects also constitute the basic principles followed by the embodied cognition perspective on Translation Psychology, as mentioned above. Fundamentally, research on Translation Psychology, by its nature, involves multidisciplinary cognitive approaches. Epistemologically, the embodied cognition perspective indicates that the translation or interpreting behaviour or the translator's habitus cannot be reduced to a collection of purely intellectual skills or a mindset. It is an embodied, somatic disposition comprising both affective and cognitive dimensions based on certain informational and environmental features. ${ }^{7}$ The above theoretical idea can lead the embodied cognitive approach to a more comprehensive way of multidimensional research on translation psychology, as argued by Zhu (2012c).

The embodied cognitive translation studies are still at an infant stage of thinking about the integrated way cognition is explored and need to be expanded by incorporating more relevant elements that influence translation into a comprehensive explanatory framework of translation psychology. As to making the research more integrated, first of all, we may consider a multidisciplinary theoretical integration centred on the core issues and relevant elements of translation psychology. These issues and elements could include bilingual processing and the psychology of transfer in the translation/interpreting process, which can be developed on the basis of the embodied cognition paradigm and the research on bilingualism and cognition in psycholinguistics, neurolinguistics, etc.

Meanwhile, the multidisciplinary theoretical integration needs to be based on multidimensional research on translation psychology. The multiple dimensions of the research cover not only the translator's cognitive psychology of skill acquisition in broad sociocultural and professional contexts but also their multi-model and dynamic psychology of bilingual processing in the translation process. In addition, the research must also explain the major 
Zhu, L. (2020). A critical review of the research on Translation Psychology: Theoretical and methodological approaches. Linguistica Antverpiensia, New Series: Themes in Translation Studies, 19, 53-79

properties and mental faculties of translation psychology and the neurocognition of the translation process. Finally, it may also involve the impact of the technology-driven translation profession on the translator's psychology and the translator's distributed cognition in the new networking environment. It is hoped that the above tentative suggestion might draw more attention to this line of research.

\section{Conclusion}

Taken together, the four approaches to Translation Psychology discussed in this article highlight the complexity of the phenomena involved. These complex phenomena broaden our horizon of research not only with a more panoramic view of the translator in the socioculturally, historically and professionally embedded working environments and networks but also with more systematic and hierarchical research areas and theoretical perspectives related to the translator's psychology. The complexity of Translation Psychology may, of course, not be completely covered by these four approaches. However, the psychological angles remind us of the fact that the translator is not merely an intelligent bilingual agent but also an emotional, active and creative mediator between two languages and cultures in general and two texts (ST and TT) in particular. Therefore, perhaps what we derive most from the four approaches discussed here is a more holistic and connectionist way of thinking, one that is necessary for Cognitive Translation Studies in addition to the specific theoretical and methodological issues.

\section{Funding details:}

This work was supported by the Chinese Fund for the Humanities and Social Science under Grant No. 20 AYY003.

\section{References}

Alves, F., Szpak, K. S., Gonçalves, J. L., Sekino, K., Aquino, M., Araújo e Castro, R., Koglin, A., de Lima Fonseca, N. B., \& Mesa-Lao, B. (2016). Investigating cognitive effort in post-editing: A relevancetheoretical approach. In S. Hansen-Schirra \& S. Grucza (Eds.), Eyetracking and applied linguistics (pp. 109-142). Language Science Press. https://doi.org/10.17169/langsci.b108.296

Angelone, E. (2015). The impact of process protocol self-analysis on errors in the translation product. In M. Ehrensberger-Dow, B. E. Dimitrova, S. Hubscher-Davidson, \& U. Norberg (Eds.), Describing cognitive processes in translation: Acts and events (pp. 105-123). John Benjamins. https://doi.org/10.1075/bct.77.07ang

Bandura, A. (1986). Social foundations of thought and action: A social cognitive theory. Prentice Hall.

Bell, R. T. (1991). Translation and translating: Theory and practice. Longman. https://doi.org/10.7202/ $\underline{002801 a r}$ 
Zhu, L. (2020). A critical review of the research on Translation Psychology: Theoretical and methodological approaches. Linguistica Antverpiensia, New Series: Themes in Translation Studies, 19, 53-79

Bolaños Medina, A. (2016). Translation psychology within the framework of translator studies: New research perspectives and pedagogical implications. In C. Martín \& V. González (Eds.), From the lab to the classroom and back again: Perspectives on translation and interpreting training (pp. 59-100). Peter Lang.

Campbell, S. (2000). Choice network analysis in translation research. In M. Olohan (Ed.), Intercultural faultlines: Research models in translation studies I: Textual and cognitive aspects (pp. 29-42). St. Jerome.

Carl, M., Bangalore, S., \& Schaeffer, M. (2016). New directions in empirical translation process research. Springer.

Carl, M., \& Dragsted, B. (2012). Inside the monitor model: Processes of default and challenged translation production. TC3, Translation: Computation, Corpora, Cognition, 2(1), 127-145.

Chesterman, A. (2009). The name and nature of translator studies. Hermes: Journal of Language and Communication Studies, 42, 13-22. https://doi.org/10.7146/hjlcb.v22i42.96844

Chesterman, A. (2011). Translation Universals. In Y. Gambier \& L. van Doorslaer (Eds.), Handbook of translation studies (Vol. 2, pp. 175-179). John Benjamins. https://doi.org/10.1075/hts.2.tra12

Christensen, T. P. (2011). Studies on the mental processes in translation memory-assisted translation: The state of the art. Trans-kom, 4(2), 137-160.

Clancey, W. J. (1997). Situated cognition. Cambridge University Press.

Clark, A. (1999). An embodied cognitive science? Trends in Cognitive Sciences, 3(9), 345-351. https:// doi.org/10.1016/S1364-6613(99)01361-3

Clark, A. (1997). Being There: Putting Brain, Body, and World Together Again. Cambridge, MA: MIT Press.

Dawson, M. (2014). Embedded and Situated Cognition. In Lawrence Shapiro (Ed.), The Routledge Handbook of Embodied Cognition (pp. 59-67). New York: Routledge.

Danks, J. H., \& Griffin, J. (1997). Reading and translation: A psycholinguistic approach. In J. H. Danks, G. M. Shreve, S. B. Fountain, \& M. K. McBeath (Eds.), Cognitive process in translation and interpreting (pp. 161-175). SAGE.

Danks, J. H., Shreve, G. M., Fountain, S. B., \& McBeath, M. K. (Eds.). (1997). Cognitive process in translation and interpreting. SAGE.

De Groot, A. M. B. (1997). The cognitive study of translation and interpretation: Three approaches. In J. H. Danks, G. M. Shreve, S. B. Fountain, \& M. K. McBeath (Eds.), Cognitive process in translation and interpreting (pp. 25-56). Sage.

Ding, G. (2011). 认知语法视角下的意向分析与翻译 [The image analysis and translation from the perspective of cognitive grammar]. Zhejiang University Press.

Dong, Y., \& Lin, J. (2013). Parallel processing of the target language during source language comprehension in interpreting. Bilingualism: Language and Cognition, 16(3), 682-692. https:// doi.org/10.1017/S1366728913000102

Ehrensberger-Dow, M. (2014). Challenges of translation process research at the workplace. MonTI Special Issue, 1, 355-383. https://doi.org/10.6035/MonTI.2014.ne1.12

Ehrensberger-Dow, M., \& Massey, G. (2014). Cognitive ergonomic issues in professional translation. In J. W. Schwieter \& A. Ferreira (Eds.), The Development of translation competence: Theories and methodologies from psycholinguistics and cognitive science (pp. 58-86). Cambridge Scholars. 
Zhu, L. (2020). A critical review of the research on Translation Psychology: Theoretical and methodological approaches. Linguistica Antverpiensia, New Series: Themes in Translation Studies, 19, 53-79

Elmer, S., Meyer, M., \& Jancke, L. (2010). Simultaneous interpreters as a model for neuronal adaptation in the domain of language processing. Brain Research, 1317, 147-156. https://doi.org/10.1016/ j.brainres.2009.12.052

Feng, B. (1994). 翻译与思维 [Translation and thinking]. Journal of Beijing International Studies University, 4, 8-11.

Feng, J. (2018). 中英双向互译中翻译认知过程研究: 基于眼动追踪和键盘记录的实证分析 [The cognitive process of translating between English and Chinese: An eye-tracking and keylogging research] . Foreign Language Teaching and Research Press.

Ferreira, A., \& Schwieter, J. W. (2015). Psycholinguistic and cognitive inquiries into translation and interpreting. John Benjamins. https://doi.org/10.1075/btl.115

Gabryś-Barker, D. (2009). Turn on your tap: memory in language processing. Linguística-Revista de Estudos Linguísticos da Universidade do Porto, 4, 25-43.

García, A. M. (2019). The neurocognition of translation and interpreting. John Benjamins. https://doi. org/10.1075/btl.147

Gerver, D. (1976). Empirical studies of simultaneous interpretation: A review and a model. In R. W. Brislin (Ed.), Translation: Applications and research (pp. 165-207). Gardner.

Gong, G. (2004). 翻译思维学 [Translation Thinking]. Shanghai Social Sciences Press.

Göpferich, S., Alves, F., \& Mees, I. (2011). New approaches in translation process research. Samfundslitteratur.

Halverson, S. (2010). Cognitive translation studies: Developments in theory and method. In G. M. Shreve \& E. Angelone (Eds.), Translation and cognition (pp. 349-369). John Benjamins. https:// doi.org/10.1075/ata.xv.18hal

Hansen, G. (2008). The speck in your brother's eye-the beam in your own. In G. Hansen, A. Chesterman, \& H. Gerzymisch-Arbogast (Eds.), Efforts and models in interpreting and translation research (pp. 255-280). John Benjamins. https://doi.org/10.1075/btl.80.19han

Hatzidaki, A. (2013). A cognitive approach to translation: The psycholinguistic perspective. In A. Rojo \& I. Ibarretxe-Antuñano (Eds.), Cognitive linguistics and translation: Advances in some theoretical models and applications (pp. 395-414). De Gruyter Mouton. https://doi.org/10.1515/97831103 $\underline{02943.395}$

Hatzidaki, A. (2019). Using experimental approaches to study translation: The what and how. Translation, Cognition \& Behavior, 2(1), 35-54. https://doi.org/10.1075/tcb.00018.hat

Hermans, T. (1999). Translation in systems: Descriptive and system-oriented approaches explained. St. Jerome.

Hervais-Adelman, A., Moser-Mercer, B., \& Golestani, N. (2015). Brain functional plasticity associated with the emergence of expertise in extreme language control. Neurolmage, 114, 264-274. https://doi.org/10.1016/j.neuroimage.2015.03.072

Holmes, J. (1972/1988). The name and nature of translation studies. In J. S. Holmes (Ed.), Translated!: Papers on literary translation and translation studies (pp. 67-80). Rodopi.

Huang, Z. (2012). 翻译思维研究进展与前瞻 [The development and prospect of the research on translation thinking] . Journal of Foreign Languages, 169(6), 103-107.

Hubscher-Davidson, S. (2013). The role of intuition in the translation process. Translation and Interpreting Studies, 8(2), 211-232. https://doi.org/10.1075/tis.8.2.05hub 
Zhu, L. (2020). A critical review of the research on Translation Psychology: Theoretical and methodological approaches. Linguistica Antverpiensia, New Series: Themes in Translation Studies, 19, 53-79

Hubscher-Davidson, S. (2018). Translation and emotion. Routledge. https://doi.org/10.4324/9781315 $\underline{720388}$

Hvelplund, K. (2017). Eye tracking in translation process research. In J. W. Schwieter \& A. Ferreira, (Eds.), The handbook of trans/ation and cognition (pp. 248-264). Wiley-Blackwell. https://doi.org/10. 1002/9781119241485.ch14

Jääskeläinen, R. (2012). Translation psychology. In Y. Gambier \& L. van Doorslaer (Eds.), Handbook of translation studies (Vol. 3 , pp. 191-197). John Benjamins. https://doi.org/10.1075/hts.3.tra14

Jääskeläinen, R. (2017). Verbal reports. In J. W. Schwieter \& A. Ferreira (Eds.), The handbook of translation and cognition (pp. 213-231). Wiley-Blackwell. https://doi.org/10.1002/9781119241 $\underline{485 . \operatorname{ch} 12}$

Jakobsen, A. L. (2003). Effects of think aloud on translation speed, revision and segmentation. In F. Alves (Ed.), Triangulating translation: Perspectives in process-oriented research (pp. 69-95). John Benjamins. https://doi.org/10.1075/btl.45.08jak

Jakobsen, A. L. (2017). Translation process research. In A. Ferreira \& J. W. Schwieter (Eds.), The handbook of translation and cognition (pp. 21-50). Wiley-Blackwell. https://doi.org/10.1002/ 9781119241485.ch2

Jay, T. B. (2000). Why we curse: The neuro-psycho-social model of speech. John Benjamins. https://doi. org/10.1075/z.91

Jay, T. B. (2004). The psychology of language. Peking University Press.

Jiang, Q. (2002). 文学翻译中的审美过程: 格式塔意象再造 [Aesthetic progression in literary translation: Image-G actualization]. The Commercial Press.

Kang, Z. (2018). 双语转换代价与口译增效策略 [Bilingual switching cost and interpreting synergism strategies]. Foreign Language Education, 3, 84-89.

Kiraly, D. C. (1995). Pathways to translation: Pedagogy and process. Kent State University Press.

Kiraly, D. C. (1997). Think-aloud protocols and the construction of a professional translator self-concept. In J. H. Danks, G. M. Shreve, S. B. Fountain, \& M. K. McBeath (Eds.), Cognitive process in translation and interpreting (pp. 137-160). Sage.

Komissarov, V. N. (1995). Intuition in translation. Target, 7(2), 347-354. https://doi.org/10.1075/target. 7.2.10kom

Krings, H. P. (1987). The use of introspective data in translation. In C. Faerch \& G. Kasper (Eds.), Introspection in second language research (pp. 159-176). Multilingual Matters.

Kussmaul, P. (1997). Comprehension process and translation: A think-aloud Protocol (TAP) study. In M. Snell-Hornby, Z. Jettmarova, \& L. Kaindl (Eds.), Translation as intercultural communication (pp. 239-247). John Benjamins. https://doi.org/10.1075/btl.20.24kus

Lakoff, G., \& Johnson, M. (1999). Philosophy in the flesh: The embodied mind and its challenge to western thought. Basic Books.

Lefevere, A. (1992). Translation, rewriting and the manipulation of literary fame. Routledge.

Li, Y., \& Liu, Y. (2008). 翻译心理学导论 [Introduction to translation psychology]. Tsinghua University Press.

Lin, J., \& Dong, Y. (2011). When does language reformulation start in Chinese-English consecutive interpreting: The serial view or the parallel view? Journal of Foreign Languages, 4, 56-63.

Lin, J., Dong, Y., \& Cai, R. (2015). 口译中源语理解和语码重构在资源分配上的层级关系 [The 
Zhu, L. (2020). A critical review of the research on Translation Psychology: Theoretical and methodological approaches. Linguistica Antverpiensia, New Series: Themes in Translation Studies, 19, 53-79

hierarchical relation in resource allocation between source language comprehension and language reformulation in interpreting]. Foreign Language Teaching and Research, 3, 447-457.

Liu, H. (2009). 汉英翻译与跨语认知 [English-Chinese translation and crosslingual cognition]. Nanjing University Press.

Liu, S. (2007). 翻译心理学 [The psychology of translating]. Wuhan University Press.

Lörscher, W. (1986). Linguistic aspects of translation processes: Toward an analysis of translation performance. In J. House \& S. Blum-Kulka (Eds.), Interlingual and intercultural communication: Discourse and cognition in translation and second language acquisition studies (pp. 277-292). Narr.

Lu, Z., \& Sun, J. (2018). 人工翻译和译后编辑中认知加工的眼动实验研究 [An eye-tracking study of cognitive processing in human translation and post-editing]. Foreign Language Teaching and Research, 5, 760-769.

Ma, H. (2016). 翻译过程中认知语境等值的界面研究 [An integrated study of the cognitive contextual equivalence in translating process]. China Social Sciences Press.

Mees, I. M., Alves, F., \& Göpferich, S. (2009). Methodology, technology and innovation in translation process research: A tribute to Arnt Lykke Jakobsen. Samfundslitteratur.

Moser-Mercer, B. (1978). Simultaneous interpretation: A hypothetical model and its practical application. In D. Gerver \& H. W. Sinaiko (Eds.), Language communication and interpretation (pp. 353-368). Plenum Press. https://doi.org/10.1007/978-1-4615-9077-4 31

Moser-Mercer, B. (1997). Beyond curiosity: Can interpreting research meet the challenge? In J. H. Danks, G. M. Shreve, S. B. Fountain, \& M. K. McBeath (Eds.), Cognitive processes in translation and interpreting (pp. 176-195). SAGE.

Muñoz Martín, R. (2009). Expertise and environment in translation. Mutatis Mutandis, 2(1), 24-37.

Muñoz Martín, R. (2010a). Leave no stone unturned: On the development of cognitive translatology. The Journal of the American Translation and Interpreting Studies Association, 5(2), 145-162. https://doi.org/10.1075/tis.5.2.01mun

Muñoz Martín, R. (2010b). On paradigms and cognitive translatology. In G. M. Shreve \& E. Angelone (Eds.), Translation and cognition (pp. 169-187). John Benjamins. https://doi.org/10.1075/ata.xv. $\underline{10 \mathrm{mun}}$

Muñoz Martín, R. (2013). More than a way with words: The interface between cognitive linguistics and cognitive translatology. In A. Rojo \& I. Ibarretxe-Antuñano (Eds.), Cognitive linguistics and translation: Advances in some theoretical models and applications (pp. 75-97). De Gruyter Mouton. https://doi.org/10.1515/9783110302943.75

Muñoz Martín, R. (2014). Situating translation expertise: A review with a sketch of a construct. In J. W. Schwieter \& A. Ferreira (Eds.), The development of translation competence: Theories and methodologies from psycholinguistics and cognitive science (pp. 2-57). Cambridge Scholars.

Muñoz Martín, R. (Ed.). (2016). Reembedding translation process research. John Benjamins. https://doi. org/10.1075/btl.128

O'Brien, S. (Ed.). (2011). Cognitive explorations of translation. Continuum International.

O'Brien, S. (2013). The borrowers: Researching the cognitive aspects of translation. Target, 25(1), 5-17.

Olvera Lobo, M. D., Robinson, B., Castro Prieto, M. R., Quero Gervilla, E., Muñoz Martín, R., Muñoz Raya, E., Murillo Melero, M., Senso Ruiz, J. A., Vargas Quesada, B., \& Diez Lerma, J. L. (2007). A 
Zhu, L. (2020). A critical review of the research on Translation Psychology: Theoretical and methodological approaches. Linguistica Antverpiensia, New Series: Themes in Translation Studies, $19,53-79$

professional approach to translator training (PATT). Meta, 52(3), 517-528. https://doi.org/10. $\underline{7202 / 016736 a r}$

Olvera Lobo, M. D., Robinson, B., Senso Ruiz, J. A., Muñoz Martín, R., Muñoz Raya, E., Murillo Melero, E., Quero Gervilla, E., Castro Prieto, M. R., \& Conde Ruano, T. (2009). Teleworking and collaborative working environments in translation training. Babel, 55(2), 165-180. https://doi. org/10.1075/babel.55.2.05olv

Proverbio, A. M., Leoni, G., \& Zani, A. (2004). Language switching mechanisms in simultaneous interpreters: An ERP study. Neuropsychologia, 42(12), 1636-1656. https://doi.org/10.1016/j. neuropsychologia.2004.04.013

Rinne, J. O., Tommola, J., Laine, M., Krause, B. J., Schmidt, D., Kaasinen, V., Teräs, M., Sipilä, H., \& Sunnari, M. (2000). The translating brain: Cerebral activation patterns during simultaneous interpreting. Neuroscience Letters, 294(2), 85-88. https://doi.org/10.1016/S0304-3940(00)0154 $\underline{0-8}$

Risku, H. (2002). Situatedness in translation studies. Cognitive Systems Research, 3(3), 523-533. https://doi.org/10.1016/S1389-0417(02)00055-4

Risku, H. (2010). A cognitive scientific view on technical communication and translation: Do embodiment and situatedness really make a difference? Target, 22(1), 94-111. https://doi.org/ 10.1075/target.22.1.06ris

Risku, H. (2014). Translation process research as interaction research: From mental to socio-cognitive processes. MonTI: Minding Translation [Special Issue], 331-353. https://doi.org/10.6035/MonTI. 2014.ne1.11

Risku, H., \& Windhager, F. (2013). Extended translation: A sociocognitive research agenda. Target, 25(1), 33-45. https://doi.org/10.1075/target.25.1.04ris

Robinson, D. (1991). The translator's turn. The Johns Hopkins University Press.

Robinson, D. (1996). Translation and taboo. Northern Illinois University Press.

Robinson, D. (1997). What is translation? Centrifugal theories, critical interventions. Kent State University Press. https://doi.org/10.21038/ksup.1997.0001

Robinson, D. (2001). Who translates?: Translator subjectivities beyond reason. State University of New York Press.

Robinson, D. (2003). Performative linguistics: Speaking and translating as doing things with words. Routledge. https://doi.org/10.4324/9780203222850

Rojo, A., \& Ibarretxe-Antuñano, I. (2013). Cognitive linguistics and translation. De Gruyter Mouton. https://doi.org/10.1515/9783110302943

Saldanha, G., \& O'Brien, S. (2014). Research methodology in translation studies. Routledge. https:// doi.org/10.4324/9781315760100

Schwieter, J. W., \& Ferreira, A. (Eds.). (2017). The handbook of translation and cognition. WileyBlackwell. https://doi.org/10.1002/9781119241485

Setton, R. (1999). Simultaneous interpretation: A cognitive-pragmatic analysis. John Benjamins. https://doi.org/10.1075/btl.28

Shreve, G. M. (2012). Bilingualism and translation. In Y. Gambier \& L. van Doorslaer (Eds.), Handbook of translation studies (Vol. 3, pp.1-6). John Benjamins. https://doi.org/10.1075/hts.3.bil1

Shreve, G. M., \& Angelone, E. (Eds.). (2010). Trans/ation and cognition. John Benjamins. https://doi. 
Zhu, L. (2020). A critical review of the research on Translation Psychology: Theoretical and methodological approaches. Linguistica Antverpiensia, New Series: Themes in Translation Studies, 19, 53-79

\section{org/10.1075/ata.xv}

Shreve, G. M., \& Koby, G. S. (1997). Introduction: What's in the 'black box'? Cognitive science and translation studies. In J. H. Danks, G. M. Shreve, S. B. Fountain, \& M. K. McBeath (Eds.), Cognitive processes in translation and interpreting (pp. xi-xviii). SAGE.

Shreve, G. M., \& Lacruz, I. (2017). Aspects of a cognitive model of translation. In J. W. Schwieter \& A. Ferreira (Eds.), The handbook of translation and cognition (pp.127-143). Wiley-Blackwell. https:// doi.org/10.1002/9781119241485.ch7

Simeoni, D. (1998). The pivotal status of the translator's habitus. Target, 10(1), 1-39. https://doi.org/ 10.1075/target.10.1.02sim

Snell-Hornby, M. (1995). Translation studies: An integrated approach (Rev. ed.). John Benjamins. https://doi.org/10.1075/z.38

Solso, R. L, MacLin, M. K., \& MacLin, O. H. (2005). Cognitive psychology (7th ed.). Pearson.

Tan, Y. (2012). 认知翻译学探索: 创造性翻译的认知路径与认知机制 [Prolegomena to cognitive translation studies: Cognitive paths and constraints of creative translation]. Shanghai Foreign Language Education Press.

Tirkkonen-Condit, S. (Ed.). (1991). Empirical research in translation and intercultural studies: Selected papers of the TRANSIF seminar, Savonlinna, 1988. Narr.

VandenBos, G. R. (Ed.). (2015). APA dictionary of psychology (2nd ed.). American Psychological Association. https://doi.org/10.1037/14646-000

Wang, B. (1992). 文化与翻译三论一一论东西方思维方法差异及其翻译 [Culture and translation: Difference in thinking methods between East and West and translation]. Foreign Language Education, 4, 67-73.

Wang, H. (2002). 英汉翻译综合教程 [Coursebook on English-Chinese translation]. Liaoning Normal University Press.

Wang, Y. (2001). 关于思维方式与翻译 [Thinking modes and translation]. Foreign Languages and Their Teaching, 3, 45-48.

Wen, X., \& Xiao, K. (2019). 认知翻译学 [Cognitive translatology]. Peking University Press.

Wilss, W. (1982). The science of translation: Problems and methods. Narr.

Wilss, W. (1996). Knowledge and skills in translator behavior. John Benjamins. https://doi.org/10. $\underline{1075 / \mathrm{btl} .15}$

Xiao, K. (2017). 诗歌翻译中的框架操作: 中国古诗英译认知研究 [Frame operation in poetry translation: A cognitive approach to English translation of classical Chinese poetry]. Science Press.

Yan, F. (2016). 翻译过程的认知机制研究 [The cognitive mechanism of the process of translation]. World Publishing Press.

Yan, L. (2008). 翻译认知心理学 [Cognitive psychology of translating]. Science Press.

Zasyekin, S. (2010). Translation as a psycholinguistic phenomenon. Journal of Psycholinguist Research, 39, 225-234. https://doi.org/10.1007/s10936-009-9134-2

Zhang, G. (2001). 英汉互译思维概论 [An introduction to the thinking between English and Chinese]. Foreign Language Teaching and Research Press.

Zhao, C. (2013). 中英不平衡双语者口译中的源语理解过程 [A study on the Chinese-English bilinguals' comprehension processes of the source language in interpreting]. Foreign Language Teaching and Research, 1, 93-104. 
Zhu, L. (2020). A critical review of the research on Translation Psychology: Theoretical and methodological approaches. Linguistica Antverpiensia, New Series: Themes in Translation Studies, 19, 53-79

Zhong, W., \& Zhu, L. (2015). 具身认知视角下的翻译认知心理特征与过程 [Formulating translator's psychology from the embodied cognition perspective]. Journal of Foreign Languages, 6, 68-78.

Zhu, L. (2012a). The translator-centered multidisciplinary construction: Douglas Robinson's translation theories explored. Peter Lang. https://doi.org/10.3726/978-3-0351-0466-0

Zhu, L. (2012b). Rethinking the interdisciplinary construction of translatology in the context of the "ecological turn": Philosophical and theoretical analysis. T\&I Review, 2, 53-78.

Zhu, L. (2012c). 论具身认知范式作为整合翻译研究的契机 [Toward integrated translation research inspired by the embodied cognition paradigm]. In Z. X. Tan \& G. S. Hu (Eds.), 翻译与跨文化交 流: 积淀与视角 [Translation and intercultural communication: Impacts and perspectives] (pp. 141-159). Shanghai Foreign Language Education Press.

Zhu, L. (2017). 社会认知视角下的翻译规范描写研究-一以中国历史上三次翻译高潮为例 [A social-cognitive explanation of the evolution of translation norms: Historical analysis of the three high periods of Chinese translation]. Foreign Languages in China, 4, 6-14.

Zhu, L. (2018). An embodied cognition perspective on translation education: Philosophy and pedagogy. Perspectives: Studies in Translation Theory and Practice, 26(1), 135-152. https://doi.org/10.1080/ $\underline{0907676 X .2017 .1328449}$

1 Other research approaches or studies are related to Translation Psychology (see Bolaños Medina, 2016). These include the interpretive approach of the Paris School, which has its origins in Piaget's developmental psychology. In addition, research into (or search for) translation universals (e.g., Chesterman, 2011) is also partly based on the assumption that psychological mechanisms may be involved in translating which result in features shared by all (or most) translations irrespective of the language pair in question (see Jääskeläinen, 2012, p. 192). But they are not the direct psychological approach as presented in this article and are therefore not included in the present discussion.

2 See http://pagines.uab.cat/trec/ for more information on the TREC network and group members. Accessed on 5 June 2020.

3 More keywords of their research can be searched for on their webpage: http://pagines.uab.cat/trec/research-projects, accessed on 5 June 2020.

4 Although in his models Hansen (2008) considers SL and TL simultaneously in the translation and revision processes, the emphasis in the models was placed on a comparison of SL and TL elements, which were considered as the quality parameters for translation and revision processes, rather than on the bilingual processing in the translation process.

5 Of course, this is not a clearcut division. In practical operation, different layers are interrelated and each layer presents a certain inner hierarchy because of the bidirectional thinking (top-down and bottom-up directions) in textual analysis and construction. In addition, the four letters "a/b/c/d" standing for norms in the same part signify the diversity and competition of major norms and minor norms in a certain historical period (see Zhu, 2012b, p. 73).

6 The label Cognitive Translatology, as translated from Chinese in these books, refers to cognitive-linguistic approaches in China. It is a different use from the standard use, as coined by Muñoz Martín (2010b), referring to 4EA-based approaches. 
Zhu, L. (2020). A critical review of the research on Translation Psychology: Theoretical and methodological approaches. Linguistica Antverpiensia, New Series: Themes in Translation Studies, 19, 53-79

7 See Hubscher-Davidson (2018) for an analysis of the emotional intelligence of translators, which argued that "alongside the study of purely cognitive processes, the psychology of translation must also encompass the study of attitudes, personalities, and dispositions" (p. 3). 